\title{
Health conditions of young and old elderly
}

\author{
Condições de saúde de idosos jovens e velhos
}

Cibelle Barbosa Reis ${ }^{1}$, Rozeli Santos de Jesus ${ }^{1}$, Carla Silvana de Oliveira e Silva ${ }^{1,2}$, Lucinéia de Pinho ${ }^{1,2}$

Objective: to evaluate the elderly about the socio-demographic profile and health conditions in the age groups from 60 to 75 years old ("young" elderly) and above 76 years ("old" elderly). Methods: this is a cross-sectional study and home based. The data were collected applying a questionnaire based on the model developed by the Older Americans Resources and Services. Results: 118 elderly participated in the study, being 68.6\% "young", $58 \%$ illiterate, $85.2 \%$ with income less than two minimum wages and $70.4 \%$ with non-white skin. The "old" elderly had a higher proportion of loss of the companion $(\mathrm{p}=0.002)$, non-communicable chronic diseases $(\mathrm{p}=0.023)$ and dependence to perform activities of daily living $(\mathrm{p}=0.036)$. Both age groups had low physical activity, excessive consumption of medicaments and chewing problems. Conclusion: the model of health facing the elderly, should not be restricted to treatment of diseases but cover their functional capacity.

Descriptors: Aged; Aging; Health Status; Primary Health Care.

Objetivo: avaliar os idosos quanto ao perfil socioeconômico e condições de saúde nas faixas etárias de 60 a 75 anos de idade (idosos "jovens") e acima de 76 anos (idosos "velhos"). Métodos: estudo transversal de base domiciliar. Coletaram-se os dados aplicando-se um questionário baseado no modelo desenvolvido pelo Older Americans Resources and Services. Resultados: participaram do estudo 118 idosos, sendo 68,6\% "jovens", 58\% analfabetos, 85,2\% com renda inferior a dois salários mínimos e 70,4\% com pele não branca. Os idosos "velhos" tiveram maior proporção de perda do companheiro $(p=0,002)$, doenças crônicas não transmissíveis $(p=0,023)$ e dependência para realização de atividades de vida diária $(\mathrm{p}=0,036)$. Ambas faixas etárias tinham baixa atividade física, excesso de consumo de medicamentos e problemas de mastigação. Conclusão: o modelo de saúde voltado a idosos não deve se restringir ao tratamento de doenças, mas abranger sua capacidade funcional.

Descritores: Idoso; Envelhecimento; Nível de Saúde; Atenção Primária à Saúde.

\footnotetext{
${ }^{1}$ Faculdades Santo Agostinho. Montes Claros, MG, Brazil.

${ }^{2}$ Universidade Estadual de Montes Claros. Montes Claros, MG, Brazil.

Corresponding author: Lucinéia de Pinho

Av. Osmane Barbosa, 937, JK, CEP: 39404-006. Montes Claros, MG, Brazil. E-mail: lucineiapinho@hotmail.com
} 


\section{Introduction}

Population aging is a worldwide phenomenon. The World Health Organization predicts that in 2025 there will exist 1.2 billion people over 60 years in the world, 34 million of them in Brazil, raising it to the 6th position among the most aged countries in the world $^{(1)}$. In developing countries, people over 60 years are considered elderly, while in developed countries the elderly are older than 65 years $^{(2)}$.

Old age can be subdivided into sub-phases, which is important in studies of this group since individuals of coming ages present more similar results and also because a general analysis of the elderly population does not produce reliable results ${ }^{(3)}$. Thus, elderly can be classified into age groups that include those most active, youthful and vigorous, or those suffering a substantial loss of function and are more likely to be frail and sick and have difficulty to manage some activities of daily living ${ }^{(3)}$.

As age advances, there is a progressive loss of health and physical functioning ${ }^{(4)}$. The elderly are carriers, on average, at least of three noncommunicable chronic diseases, and have a higher probability of hospitalization. Therefore, the comprehensive health care through the Unified Health System (SUS), is essential for promoting quality of life and health of the elderly ${ }^{(5-6)}$ and even is assured in the Elderly Statute.

The Unified Health System must ensure to the elderly, universal and equal access to services and actions for the prevention of disease, as well as the promotion, protection and health recovery, including special attention to diseases affecting this age group preferably. However, health professionals face challenges about this situation, due to the lack of gerontological knowledge, devaluation of continuing education and training for elderly care ${ }^{(7)}$.

The health conditions and environmental factors influence the daily activities of the elderly ${ }^{(4)}$. The health of the elderly does not depend simply on the presence or absence of disease, but the emotional state, lifestyle habits (smoking, diet, physical activity, leisure), social factors (family, friends) ${ }^{(8)}$ and economic factors ${ }^{(9)}$. Active aging can be healthier than the absence of disease.

There are comprehensive policies with actions aimed at elderly individual and social groups, that promote the creation of a physical, social, political, economic and cultural environment, propitious for old age and encourage the community effort ${ }^{(5)}$. This is the case of the Family Health Strategy government program, which includes among its objectives, the suitable approach to the elderly as an individual requiring community care.

The Family Health Strategy teams need, along to the elderly family, to provide him a bond with the local health system. These teams can also assist in data collection about the health conditions of the elderly population that can be evaluated by specific indicators, such as morbidity and mortality profile, physical and cognitive problems and use of health services.

Given the above, the study of the elderly profile, as part of the Family Health Strategy, is the best way to know this segment of the population and promote action plans geared to the needs and contextualized to the social reality.

This work aimed to evaluate the elderly and the socioeconomic and health profile, within the age groups from 60 to 75 years old ("young" elderly) and above 76 years ("old" elderly).

\section{Methods}

This work constitutes in a cross-sectional study and home based, conducted by the Family Health Strategy service, of the urban area of the municipality of Pedras de Maria da Cruz, Minas Gerais, Brazil, in the second half of 2011. The study included elderly (over 60 years) registered in the Basic Care Information System, identified in the Registration Records of 
Families - Form A (N=197). The charts were identified with the help of community health workers of the Family Health Strategy team in the municipality.

For this study, the sampling procedure was a simple random type, from the registered elderly. The participation of at least 114 elderly was estimated, considering the following criteria, for sample calculation: the total number of elderly, $95 \%$ confidence level and a sampling error of $6 \%$ and the prevalence of health problems in $50 \%$ of the elderly population.

The study included the elderly who met the following inclusion criteria: agreed to participate in the survey; were registered in the Basic Care Information System during the data collection period; were found at the residence of two contact attempts; resided at the address registered with the service. They were inserted into the stratification of age groups of 6075 years ("young" elderly) and above 76 years ("old" elderly).

As data collection instrument, questionnaire was used, based on the model of the Older Americans Resources and Services, previously used in crosssectional studies with elderly in Brazil ${ }^{(10)}$. The questionnaire was modified to collect data about identification, social profile of the elderly, lifestyle, functional assessment, health status and family and social support network. To ensure the instrument clarity, it was evaluated at pre-test before collecting socioeconomic data (gender, marital status, education, income, origin, color, with whom they live, housing) and about health (health self-perception, diagnosis of chronic disease, regular use of medication, smoking, alcohol consumption, physical activity, and difficulties in chewing, sight, hearing and performance of activities of daily living.

Data were analyzed by the computer program Statistical Package for Social Sciences for Windows ${ }^{\circledR}$, version 18.0 and the results were presented in simple frequencies (n) and percentage (\%). Bivariate and multivariate analyzes were performed through logistic regression, thus, the stratification of the age groups from 60 to 75 years ("young" elderly) and above 76 years ("old" elderly) was considered a dependent variable, while the other characteristics of the elderly were considered independent variables. The magnitude of the association between dependent and independent variables was evaluated by the odds ratio (OR) with their respective confidence intervals of $95 \%$. The variables, whose statistical significance was greater than $30 \%$ in the bivariate analysis, were selected for multiple analyzes by the forward method. The final model was composed of the factors that remained associated with the dependent variables at 5\% error. The Hosmer and Lemeshow test evaluated the quality of the model adjustment, and the Nagelkerte test, calculated the determination coefficient.

The study respected the formal requirements contained in the national and international regulatory standards for research involving human beings.

\section{Results}

118 elderly were evaluated with a mean age of $71.50( \pm 8.90)$ years, being $68.6 \%$ "young" elderly ( $66.46 \pm 0.51$ years) and the other "old" elderly (82.5 \pm 0.86 years) (Table 1 ). As to gender, $56.0 \%$ were women. Just over a half had a companion and the presence of the companion was significantly lower among the "old" elderly $(\mathrm{p}<0.05)$. Almost $60.0 \%$ had no formal education. The income of the elderly was generally up to two minimum salaries. The majority of the elderly came from the countryside, non-white skin color, and living with other family members or particular escort, in addition to the home companion (Table 1). 
Table 1 - Socio-demographic characteristics of the elderly according to the age group

\begin{tabular}{|c|c|c|c|c|c|}
\hline \multirow[t]{2}{*}{ Variables } & $\begin{array}{c}\text { 60-75 years } \\
(\mathrm{n}=81)\end{array}$ & $\begin{array}{c}>76 \text { years } \\
(n=37)\end{array}$ & \multirow[t]{2}{*}{$\begin{array}{l}\text { Crude Odds } \\
-\quad \text { Reason }\end{array}$} & \multirow[t]{2}{*}{ CI 95\% } & \multirow{2}{*}{$\begin{array}{c}\mathrm{p}^{*} \\
\text { value }\end{array}$} \\
\hline & n(\%) & n(\%) & & & \\
\hline
\end{tabular}

Gender

\begin{tabular}{|c|c|c|c|c|}
\hline Male & $33(40.7)$ & $19(51.3)$ & & ר \\
\hline Female & $48(59.3)$ & $18(48.7)$ & 0.6 & \\
\hline
\end{tabular}

Marital status

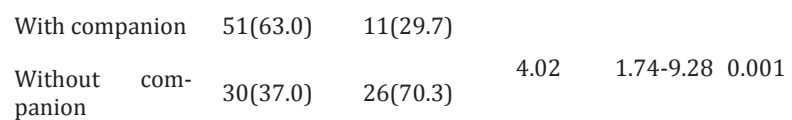

Education

Literate $\quad 34(42.0) \quad 15(40.5)$

$\begin{array}{llllll}\text { Illiterate } & 47(58.0) & 22(59.5) & 1.06 & 0.48-2.34 & 0.883\end{array}$

Income (minimum wage)

\begin{tabular}{|c|c|c|c|c|c|}
\hline More than 2 & $12(14.8)$ & $4(10.8)$ & \multirow[t]{2}{*}{1.44} & \multirow{2}{*}{\multicolumn{2}{|c|}{$0.43-4.790 .55$}} \\
\hline Up to 2 & $69(85.2)$ & $33(89.2)$ & & & \\
\hline \multicolumn{6}{|l|}{ Origin } \\
\hline Urban & $13(16.0)$ & $2(5.4)$ & \multirow{2}{*}{3.35} & \multirow{2}{*}{\multicolumn{2}{|c|}{$0.72-15.660 .12$}} \\
\hline Rural & $68(84.0)$ & $35(94.6)$ & & & \\
\hline \multicolumn{6}{|l|}{ Color } \\
\hline White & $24(29.6)$ & 11(29.7) & \multirow{2}{*}{0.99} & \multirow{2}{*}{$0.43-2.33$} & \multirow{2}{*}{0.99} \\
\hline Non-white & $57(70.4)$ & $26(70.3)$ & & & \\
\hline \multicolumn{6}{|l|}{ Living with } \\
\hline Accompanied & $67(82.7)$ & $28(75.7)$ & \multirow{2}{*}{1.54} & \multirow{2}{*}{$0.60-3.96$} & \multirow{2}{*}{0.37} \\
\hline Alone & $14(17.3)$ & $9(24.3)$ & & & \\
\hline \multicolumn{6}{|l|}{ Housing } \\
\hline Own & $77(95.1)$ & $36(97.3)$ & \multirow{2}{*}{0.54} & \multirow{2}{*}{$0.06-4.96$} & \multirow{2}{*}{0.58} \\
\hline Rented & $4(4.9)$ & $1(2.7)$ & & & \\
\hline
\end{tabular}

${ }^{*}$ Contrast of the age groups between 60 and 75 years and above 75 years; Minimum wage value in the data collection period $=\mathrm{R} \$ 545.00$; $\mathrm{Cl}=$ Confidence Interval

According to the self-evaluation of their health conditions (Table 2), few admitted to having poor health and most divided between good and regular. It is noted that in the "old" elderly the incidence of non-communicable chronic diseases was higher than in the "young" elderly $(\mathrm{p}<0.05)$. In the interviews, hypertension was reported as the main disease and spinal problems like the ones that most interfere with life. Most elderly used medicaments, and most often the "old" elderly. The doctor usually prescribed these medicaments, while the elderly make self-medication, especially painkillers. More than $17.0 \%$ of the interviewed were smokers and $25.0 \%$ ex-smokers.

Table 2 - Aspects related to elderly health according to the age group

\begin{tabular}{|c|c|c|c|c|c|}
\hline \multirow{2}{*}{ Variable } & \multicolumn{2}{|c|}{$60-75$ years $>76$ years } & \multirow{2}{*}{$\begin{array}{l}\text { Crude Odds } \\
\text { Reason }\end{array}$} & \multirow{2}{*}{ CI 95\% } & \multirow{2}{*}{$\begin{array}{c}\mathbf{p}^{*} \\
\text { value }\end{array}$} \\
\hline & n(\%) & $\mathrm{n}(\%)$ & & & \\
\hline \multicolumn{6}{|l|}{ Considers their health } \\
\hline Good/great & $36(44.4)$ & $14(37.8)$ & & & \\
\hline Regular & $37(45.7)$ & $16(43.3)$ & 1.12 & $0.48-2.61$ & 0.807 \\
\hline Bad/terrible & $8(9.9)$ & $7(18.9)$ & 2.25 & $0.69-7.38$ & 0.181 \\
\hline \multicolumn{6}{|l|}{$\begin{array}{l}\text { Non-communicable } \\
\text { chronic disease }\end{array}$} \\
\hline No & $32(39.5)$ & $6(16.2)$ & \multirow{2}{*}{3.37} & \multirow{2}{*}{$1.26-9.00$} & \multirow{2}{*}{0.012} \\
\hline Yes & $49(60.5)$ & $31(83.8)$ & & & \\
\hline \multicolumn{6}{|l|}{ Medicaments } \\
\hline No & $10(12.3)$ & $1(2.7)$ & \multirow{2}{*}{5.07} & \multirow{2}{*}{$0.63-41.17$} & \multirow{2}{*}{0.129} \\
\hline Yes & $71(87.7)$ & $36(97.3)$ & & & \\
\hline \multicolumn{6}{|l|}{ Cigarette } \\
\hline Never & $49(60.5)$ & $23(62.2)$ & & & \\
\hline $\begin{array}{l}\text { Already used and } \\
\text { stopped }\end{array}$ & $20(24.7)$ & $5(13.5)$ & 0.53 & $0.18-1.60$ & 0.261 \\
\hline Yes & $12(14.8)$ & $9(24.3)$ & 1.60 & $0.59-4.33$ & 0.357 \\
\hline \multicolumn{6}{|l|}{ Alcohol drink } \\
\hline Never & $46(56.8)$ & $26(70.3)$ & & & \\
\hline $\begin{array}{l}\text { Already used and } \\
\text { stopped }\end{array}$ & $8(9.9)$ & $4(10.8)$ & 0.89 & $0.24-3.22$ & 0.853 \\
\hline Yes & $27(33.3)$ & $7(18.9)$ & 0.46 & $0.18-1.20$ & 0.112 \\
\hline \multicolumn{6}{|l|}{ Physical activity } \\
\hline Yes & $22(27.2)$ & $7(18.9)$ & 1.60 & $0.61-4.16$ & 0.337 \\
\hline No & $59(72.8)$ & $30(81.1)$ & & & \\
\hline
\end{tabular}

Regarding physical activity, less than $25.0 \%$ reported doing light activities such as walking. Almost $40.0 \%$ of elderly reported difficulty chewing hard foods and other foods (Table 2).

Just over a half reported no difficulty of sight, and few reported having hearing difficulties. Most elderly people under 75 years old reported not having any difficulty in performing activities of daily living, but this proportion decreased statistically in "old" elderly $(\mathrm{p}<0.05)$ (Table 3). 
Table 3 - Difficulties of the elderly about the living habits according to the age group

\begin{tabular}{|c|c|c|c|c|c|}
\hline Variable & $\begin{array}{l}60-75 \\
\text { years }\end{array}$ & $\begin{array}{l}>76 \\
\text { years }\end{array}$ & $\begin{array}{l}\text { Crude Odds } \\
\text { Reason }\end{array}$ & CI 95\% & $\begin{array}{c}\mathbf{p}^{*} \\
\text { value }\end{array}$ \\
\hline \multicolumn{6}{|l|}{ Chew } \\
\hline No & $53(65.4)$ & $18(48.6)$ & \multirow[b]{2}{*}{0.50} & \multirow[b]{2}{*}{$0.23-1.10$} & \multirow[b]{2}{*}{0.086} \\
\hline Yes & $28(34.6)$ & $19(51.4)$ & & & \\
\hline \multicolumn{6}{|l|}{ Sight } \\
\hline No & $41(50.6)$ & $23(62.2)$ & \multirow[b]{2}{*}{0.63} & \multirow[b]{2}{*}{$0.28-1.38$} & \multirow[b]{2}{*}{0.244} \\
\hline Yes & $40(49.4)$ & $14(37.8)$ & & & \\
\hline \multicolumn{6}{|l|}{ Hearing } \\
\hline No & $80(98.8)$ & $36(97.3)$ & \multirow[b]{2}{*}{2.22} & \multirow[b]{2}{*}{$0.14-36.53$} & \multirow[b]{2}{*}{0.576} \\
\hline Yes & $1(1.2)$ & $1(2.7)$ & & & \\
\hline \multicolumn{6}{|c|}{ Daily activities } \\
\hline $\begin{array}{l}\text { No } \\
\text { Yes }\end{array}$ & $\begin{array}{l}67(82.7) \\
14(17.3)\end{array}$ & $\begin{array}{l}21(56.8) \\
16(43.2)\end{array}$ & 3.65 & $1.53-8.69$ & 0.003 \\
\hline
\end{tabular}

The adjusted logistic regression analysis was modeled adding variables as gender, marital status, origin, health perception, chronic disease, use of medicaments, smoking, alcohol intake, chewing difficulty, sight difficulty, hearing difficulty and activities of daily living. Table 4 shows the final results of the multivariate analysis of the characteristics associated with age. The most significant factors in the advance from "young" to "old" elderly, were increased the chance of having a chronic disease and three times difficulty in activities of daily life. Moreover, indicated that the proportion of women reaching more than 76 years was three times higher than men, and the proportion of "old" elderly over 76 years presented a chance 0.18 times greater of losing their companions.
Table 4 - Multivariate analysis of the socio-economic profile and health of the "young" and "old" elderly

\begin{tabular}{|c|c|c|c|}
\hline Variables & $\begin{array}{c}\text { Crude Odds } \\
\text { Reason }\end{array}$ & CI 95\% & $\begin{array}{c}\mathbf{p}^{*} \\
\text { value }\end{array}$ \\
\hline \multicolumn{4}{|l|}{ Gender } \\
\hline Male & 1.00 & \multirow{2}{*}{$1.20-8.58$} & \multirow[b]{2}{*}{0.020} \\
\hline Female & 3.21 & & \\
\hline \multicolumn{4}{|l|}{ Marital status } \\
\hline With companion & 1.00 & \multirow{2}{*}{$0.07-0.50$} & \multirow{2}{*}{0.001} \\
\hline Without companion & 0.18 & & \\
\hline \multicolumn{4}{|c|}{ Non-communicable chronic disease } \\
\hline No & 1.00 & \multirow{2}{*}{$1.09-9.36$} & \multirow{2}{*}{0.033} \\
\hline Yes & 3.20 & & \\
\hline \multicolumn{4}{|c|}{ Difficulty in activities of daily living } \\
\hline No & 1.00 & & \\
\hline Yes & 3.05 & $1.15-8.02$ & 0.024 \\
\hline
\end{tabular}

\section{Discussion}

With life expectancy increase of the population, it is important to know the communities of elderly people in different regions of the country, to support actions to improve their quality of life, at the national and local level. In this sense, the present study describes the profile of the elderly population attended by a Family Health Strategy in the urban area of the municipality of Pedras de Maria da Cruz, Minas Gerais, Brazil. Also, the research analyzes the parameters studied in both age groups, corresponding to "young" and "old" elderly. This approach allowed identifying the main factors and decline determinants of health conditions along the old age. 
The study of elderly by age groups is important because, besides the fact that $10 \%$ of Brazilian elderly have more than 80 years, presently, health problems can be severely aggravated from 76 years old. To identify the health conditions of older elderly enables interventions targeted to their demands, contributing to their well-being, independence, and dignity, and providing a healthier aging, which is aggregated quality of life for years, and not just years to life ${ }^{(11)}$. Besides, the adoption of preventive measures to pathological aging can contribute to the reduction of health care costs and also the decrease in total costs to society in general.

The study population, similar to other Brazilian regions, faces social inequality and poverty. The elderly were rural and mestizo skin, characteristic of the region, with a high ancestry of quilombola culture and black skin color. They still had low education, which is common in the region in the north of Minas Gerais $^{(12)}$ and lower income from the retirement and/or pension. The reported income can be sufficient for the basic supply of the family, but does not cover excessive expenses, for example, high-cost medicaments. Thus, the health of the interviewed elderly depended primarily on health services provided by the Family Health Strategy program of the municipality.

Despite socio-economic conditions or unfavorable income, most of the elderly had their house and harbored other family members. The own house is a result of patrimony accumulated for years, and some government actions have allowed the acquisition by the elderly. The family can be considered able to promote networks of sociability and solidarity, and a suitable living arrangement may be associated with better quality of life of elderly, suggesting how relevant are the family interactions, organization and family support ${ }^{(13)}$.

Some of the evaluated health variables also affect "young" and "old" elderly. The elderly showed a high rate of non-communicable chronic diseases, and it is probable that smoking contributed to its development, since $20.0 \%$ of interviewed were smokers and almost 25.0\% ex-smokers. Another problem is that the majority does not perform physical activity. The practice of physical activity for elderly can delay the functional decline, reduce chronic diseases, improve mental health and promote social contact $^{(14)}$. In this sense, actions to combat smoking and encouraging physical activity should be taken to promote health at local and regional level.

The regular use of medicaments by more than $90.0 \%$ of interviewed elderly can be considered high. This practice may be related to self-medication. The self-medication may constitute a risk factor for the use of medicaments without prescription, increasing the number of substances used by the elderly, leading to inadequate drug interactions, the presence of adverse effects and symptoms mask ${ }^{(12)}$. Despite the evidence, a more detailed study on this issue would need to understand the factors associated with high consumption of medicaments by the studied population.

Elderly does not identify sight or hearing problems, which might be due to the lack of opportunity to make diagnostic examinations of these deficiencies, which are common in this age group ${ }^{(15)}$. On the other hand, the elderly had a clear perception of difficulties in chewing, revealing the lack of care with oral health in youth and probably lack of proper dental prosthesis. With aging, chewing habits change, both in men and women. These changes in masticatory ability are often due to tooth decay and periodontal diseases, the total or partial prosthesis unsuitable or in bad condition, and the lack of teeth. Ultimately, the chewing difficulty can interfere with the nutritional status of the elderly ${ }^{(16)}$.

The identifying factors of quality of life fall from "young" to "old" elderly; a major factor identified was the higher proportion of women elderly than men. This was an expected situation seen that in the year 2011, the average life expectancy of Brazilian women with 80 years old was 9.9 years while of elderly men was a year younger ${ }^{(11)}$. Another detected factor was the companion loss, especially widowhood. The grieving 
process, normal in old age, has a negative impact on various aspects of health, including increased risk of mental disorder ${ }^{(17)}$, general health illnesses and mortality, and decreased functional capacity ${ }^{(13)}$. Indeed, the third factor of health impairment, detected in the transition from "young" to "old" elderly, was the higher incidence of non-communicable chronic diseases. Still, few elderly considered in bad health conditions and most were divided between the perceptions of good or regular health, corroborating a profile presented in Campinas, São Paulo(18).

The fourth factor that impacted the elderly to move into the phase of "old" elderly was the increase in dependence to perform activities of daily living. This dependence is recognized as one of the great components of the elderly health, emerging as a key factor to evaluate the health of this population ${ }^{(19)}$ as it scales the functional capacity of the elderly. Although most "old" interviewed elderly report that normally performs their activities, the chance of developing dependence increased in this age group, confirming previous studies showing the association between advancing age and increasing the difficulty of execution of activities of daily living ${ }^{(19)}$. Indeed, a history analysis in the country revealed that the prevalence of functional disability in the elderly remains stable, pointing out that in addition to personal and family suffering, it increases the demand for medical and social services, with corresponding costs ${ }^{(20)}$.

The limitations of this study are relevant to the cross-sectional design, preventing the results to be taken as cause and effect, due to non-verification of temporality. Also, the particular nature of the sample of elderly, i.e., the municipality of Pedras de Maria da Cruz, Minas Gerais, which, in turn, limits the extrapolation of observed data. Despite these limitations, it is believed that the unveiled overview is important for actions directed to the elderly in Primary Health Care.

\section{Conclusion}

The studied population, of poor elderly and dependent on public health services, reflects the reality of many Brazilians. In this study, it was found that the elderly were lack of physical activity, excessive consumption of medicaments and chewing problems. Also, the analysis of health conditions among the phase "young" and "old" elderly, was associated with an increased incidence of chronic diseases and to the factors that compromise the functional capacity.

The results indicate that the professionals inserted in the Family Health Strategy teams, especially nurses, should promote actions aimed at comprehensive care of the elderly, including care planning and the development of activities that aim to enhance the functional capacity of the elderly.

\section{Collaborations}

Reis CB and Jesus RS contributed to the work conception, data collection, analysis, data interpretation, article writing. Silva CSO contributed to the article writing. Pinho L contributed in wording and critical analysis of the article and final approval of the version to be published.

\section{References}

1. Bandeira EMFS, Pimenta FAP, Souza MC. Atenção à saúde do idoso. Belo Horizonte: Secretaria de Estado de Saúde de Minas Gerais; 2007.

2. Ministério da Saúde (BR). Conselho Nacional de Saúde. Estatuto do idoso. Brasília: Ministério da Saúde; 2003.

3. Rosset I, Pedrazzi EC, Roriz-Cruz M, Morais EP, Rodrigues RAP. Tendencies of studies addressing the eldest individuals of aged population in the community: a (inter)national systematic review. Rev Esc Enferm USP. 2011; 45(1):264-71. 
4. Tier CG, Santos SSC, Poll MA, Hilgert RM. Health conditions of elderly in Primary Health Care. Rev Rene. 2014; 15(4):668-75.

5. Carvalho MHR, Carvalho SMR, Laurenti R, Payão SLM. Tendência de mortalidade de idosos por doenças crônicas no município de Marília-SP, Brasil: 1998 a 2000 e 2005 a 2007. Epidemiol Serv Saúde. 2014; 23(2):347-54.

6. Ferreira JBB, Borges MJG, Santos LL, Forster AC. Internações por condições sensíveis à atenção primária à saúde em uma região de saúde paulista, 2008 a 2010. Epidemiol Serv Saúde. 2014; 23(1):45-6.

7. Tahan J, Carvalho ACD. Reflexões de idosos participantes de grupo de promoção de saúde acerca de envelhecimento e da qualidade de vida. Saúde Soc. 2010; 19(4):878-88.

8. Paskulin LMG, Côrdova FP, Costa FM, Vianna LAC. Elders' perception of quality of life. Acta Paul Enferm. 2010; 23(1):101-7.

9. Geib LTC. Determinantes sociais da saúde do idoso. Ciênc Saúde Coletiva. 2012; 17(1):123-33.

10. D'Orsi E, Xavier AJ, Ramos LR. Trabalho, suporte social e lazer protegem idosos da perda funcional: Estudo Epidoso. Rev Saúde Pública. 2011; 45(4):685-92.

11. Rosset I, Roriz-Cruz M, Santos JLF, Haas VJ, Fabrício-Wehbe SCC, Rodrigues RAP. Diferenciais socioeconômicos e de saúde entre duas comunidades de idosos longevos. Rev Saúde Pública. 2011; 45(2):391-400.

12. Silva CSO, Neto JFR, Pereira MI, Barbosa DA, Yoshitome AY. Avaliação do uso de medicamentos pela população idosa em Montes Claros, MG, Brasil. Esc Anna Nery. 2010; 14(4):811-8.
13. Rabelo DF, Neri AL. The household arrangements, physical and psychological health of the elderly and their satisfaction with family relationships. Rev Bras Geriatr Gerontol. 2015; 18(3):507-19.

14. Cordeiro J, Del Castillo BL, Freitas CS, Gonçalves MP. Efeitos da atividade física na memória declarativa, capacidade funcional e qualidade de vida em idosos. Rev Bras Geriatr Gerontol. 2014; 17(3):541-52.

15. Pilger C, Menon MH, Mathias TAF. Sociodemographic and health characteristics of elderly individuals: support for health services. Rev Latino-Am Enfermagem. 2011; 19(5):1230-8.

16. Dias-da-Costa JS, Galli R, Oliveira EA, Backes V, Vial EA, Canuto R, et al. Prevalência de capacidade mastigatória insatisfatória e fatores associados em idosos brasileiros Cad Saúde Pública. 2010; 26(1):79-88.

17. Fernandes MGM, Nascimento NFS, Costa KNFM. Prevalência e determinantes de sintomas depressivos em idosos atendidos na atenção primária de saúde. Rev Rene. 2010; 11(1):19-27.

18. Borim FSA, Barros MBA, Neri AL. Autoavaliação da saúde em idosos: pesquisa de base populacional no Município de Campinas, São Paulo, Brasil. Cad Saúde Pública. 2012; 28(4):769-80.

19. Minosso JSM, Amendola F, Alvarenga MRM, Oliveira MAC. Prevalência de incapacidade funcional e dependência em idosos atendidos em um centro de saúde-escola da Universidade de São Paulo. Cogitare Enferm. 2010; 15(1):12-8.

20. Lima-Costa MF, Matos DL, Camargos VP, Macinko J. Tendências em dez anos das condições de saúde de idosos brasileiros: evidências da Pesquisa Nacional por Amostra de Domicílios (1998, 2003, 2008). Ciênc Saúde Coletiva. 2011; 16(9):368996. 